\title{
A organização da Justiça, o Processo Penal e o Direito Penal no Brasil Holandês (*)
}

Ruy Rebello Pinho

\section{1 - Breve notícia histórica}

Em 13 de junho de 1630, uma esquadra holandesa da Companhia das Índias Ocidentais surgiu diante de Olinda. No dia seguinte, tiveram inicio os combates entre flamengos e portuguêses pela posse de Pernambuco.

Éstes combates pràticamente duraram até 1654, quando os holandeses assinaram a capitulação da Campina da Taborda, pois durante os vinte e quatro anos viviảos em Pernambuco e nas capitanias vizinhas, os invasores, em nenhum momento sequer, puderam se sentir como verdadeiros senhores das terras conquistadas.

A despeito disto, houve um tempo de maior socêgo, um período de aparente consolidação da vitória dos flamengos. Dir-se-ia criada, na Amẻrica, a Nova Holanda. Foi quando estêve à frente do govêrno de Pernambuco o conde João Maurício de Nassau-Siegen, que chegou a Recife em 23 de janeiro de 1637 e deixou o Brasil em 11 de maio de 1644.

A história da permanência dos holandeses no norte do país pode mesmo ser dividida em três período: o anterior a Nassau, o de seu govêrno, e o posterior a seu regresso para Europia.

(*) Trabalho apresentado ao Professor Waldemar Ferreira, no Curso de Doutorado, no ano letivo de 1953. 
A Companhia das fndias Ocidentais - que pretendeu assenhorear-se das colônias portuguêsas e espanholas na América - era uma companhia de mercadores, enderecados todos a um negócio mercantil, segundo diz FreI Manuel Calado (1), não desmentido por Barleu (2), nem por Watjen. (3).

Só o desejo de auferir grandes lucros impeliu os holandeses a empreenderem a conquista de Pernambuco. Felipe II lhes fechara os portos de Portugal e Espanha e êles resolveram buscar diretamente nas longínquas terras da India as mercadorias para seu comércio.

Assim, quando aqui aportaram desejavam enriquecer e nada mais. Dêste modo, os anos anteriores à vinda de Nassau foram anos, acima de tudo, de rapina. Inexiste um trabalho construtivo em prol da estruturação dum novo país. Tudo é precário. A ordem, a justiça. Constante, só o desejo de enriquecer. Mas os portuguêses não estavam dispostos a permitirem fôsse a terra em que viviam, com seus costumes, suas igrejas, seus sacerdotes, transformada, de um momento para outro, em mero celeiro de negociantes insaciáveis. $\mathrm{E}$ ofereceram tenaz resistência ao invasor. Cedo, a Companhia das índias compreendeu a necessidade de administrar a "sua fazenda" como se fôsse um Estado e de substituir os mercadores do Conselho Politico de Recife por ùm estadista.

Daí os XIX da Companhia haverem resolvido entregar o govêrno de Pernambuco ao Conde de Nassau. Que êle amava a riqueza e não desprezava os lucros, parece certo,

(1) Frei manuel Calado, o Valeroso Lucideno.

(2) Gaspar Barleu, História dos Feitos recentemente praticados durante oito anos no Brasil e noutras partes sob o govêrno do ilustrissíssimo João Maurício, Conde de Nassau etc. ora governador de Wessel, Tenente General de Cavalaria das Provincias Unidas sob o Principe de Orange.

(3) Hermann Watjen, $O$ Domínio Colonial Holandês no Brasil. 
segundo conta e sugere Frei Manuei Calado (4). Mas êle não era apenas o mercador: provam-no bem os seus atos. A cidade Mauricia, a chamada Assembléia Legislativa de 1640 , a tolerância religiosa característica de sua personalidade, são alguns dos vários sinais reveladores do talento e de um governante. Espicaçado pelo inimigo heróico e valoroso, lidando com uma população heterogênea de homens separados por muralhas religiosas e por preconceitos de raça, João Maurício merece. sem dúvida, muitos dos elogios a êle feitos.

Mas o Príncipe representava aos XIX da Companhia, que eram uns mercadores, como diz Frei Manuel Calado (5), e não se interessavam pelo progresso da colônia, só por lucros rápidos. Desejavam apenas colhêr. colhêr ainda sem plantar. Por isto, foi Nassau mandado de volta à Holanda. E. em seu lugar, remetidos ao Brasil, outros negociantes aqui vieram. A fúria usurária com que se atiravam aos bens dos habiantes da Nova Holanda levou às hostes libertadoras muitos dos antigos colaboradores do govêrno holandês. $O$ que poderia ter sido um Estado voltou à condição de fazenda. Todo o trabalho do Conde pareceu. Os escabinos deixaram de se reunir. A tolerância cedeu lugar à perseguição religiosa. Marranos foram apedrejados, católicos proibidos de celebrar o Santo Sacrifício da Missa, ou de se confessarem antes da morte. E até a cidade Maurícia entregue à destruição das chamas.

Estes três momentos da história holandesa em Pernambuco e capitanias vizinhas se refletem também na história do direito daquela época.

Antes de Nassau, tudo é incerto. As vicissitudes da conquista da terra e a inaptidão dos governantes dificultam qualquer organização judiciária. Os chefes dos con-
(4) O. b. cit.
(5) O. b. cit. 
quistadores reunem em si todos os poderes: administram, legislam e julgam. Muitas vêzes o direito, se a isto podemos chamar direito, nasce brutalmente na ponta da esnada e se nutre do desejo de rapina. E um momento de lutas cruéis. Portuguêses e holandeses negam a cada instante os sentimentos cristãos de que tanto se vangloriam.

Quando Mauricio de Nassau chega, a situação melhora. Suas vitórias nas armas afastam de Recife o inimigo. Seu espírito de organização começa a impor a ordem necessária ao convívio social. Êle procura organizar a justiça preocupa-se em saber qual o díreito a aplicar no território conquistado, pede à metrópole homens entendidos em leis para substituir inexperientes e ambiciosos mercadores aos quais havia sido entregue a missão de juIgar. Organiza o primeiro parlamento das Américas. Procura prender à terra os portuguêses; muitos, mesmo, sentem-se felizes sob a dominação do Príncipe. Nesta época è possível encontrar elementos para uma história da organização judiciäria e do direito.

Depois de Nassau ,hả um retrocesso. Condições hıstóricas favorecem o fortalecimento da resistência, que sempre existiu ao invasor. A causa da liberdade ganha novos adeptos. E a êste poder em crescimento se contrapōe outro enfraquecido. Tudo começa a desmoronar. Os escabinos perdem a importância. Os intolerantes pastores calvinistas fogem como ratos de um navio prestes a afundar, no dizer de WatJen (6). Mas isto não melhora a situação, pois muitos judeus já se haviam retírado para a Holanda e os católicos ansiavam pela expulsão do invasor hereje. $O$ direito que começara a ser escrito fica inacabado, como uma frase deixada pelo meio. Reina o caos no reduto dos batavos.

(6) O. b. cit. 


\section{2 - Organização judiciária}

Antes de Nassau - De 1630 a 1637, a direção dos negócios da Nova Holanda estêve entregue ao Conselho Político, formado, a princípio, por três funcionários da W.I.C.. vindos na esquadra conquistadora de Hendrick Corneliszoon Loncq: Johan de Bruyne, Philips Serooskerken e Horatio Calendrini.

Ao Conselho pertencia também o coronel Waerdenburch, chefe militar das tropas holandesas.

Johan de Bruyne, Philips Serooskerken e Horatio Calendrini tinham o título de conselheiros políticos: e Waerdenburch, o de governador. Isto não dava ao chefe militar uma ascendência sôbre os companheiros. Sòmente em questõs de guerra tinha êle autonomia; no mais, possuıa, como os outros, apenas um voto e, ao contrário dos conselheiros políticos, não podia exercer a presidência do Conselho.

Segundo Watjen, os XIX da Companhia das Indias deviam ter dado aos conselheiros instruções mais ou menos dêste teor: "mantende a ordem no território recem-conquistado, interessai-vos pela estrita observância dos mandamentos da Companhia, institui um tribunal de justiça. castigae todas as transgressões das nossas ordens, cuidai do sustento das tropas e entrai em preparativos imediatos para a remessa regular de assucar e madeiras de tinturaria." (7).

Eram, assim, na colônia, os membros do Conselho Político: o Poder Executivo, o Poder Legislativo e o Poder Judiciário.

Sua preocupação máxima tinha de ser a solidificação da conquista. Mal tinham tempo para cuidar de outras coisas. Sôbre seus ombros caiam tarefas pesadíssimas, Eram poucos para tão difíceis e numerosas funções.
(7)
o. b. cit. 
Dai haverem juntado a si, durante o correr do mesmo ano de 1630, mais dois companheiros: Johanenes van Walbeecke e Servatius Carpentier.

Mesmo assim o Conselho não deu conta de suas funções. Chefes civis e chefes militares se desentendiam. Uns atiravam sôbre os outros a culpa da situação má em que se encontravam. E os negócios não ofereciam à Companhia os pingues lucros desejados. Daí haver ela resolvido mandar ao Brasil dois de seus diretores: Mathias van Ceulen, de Amsterdão, e João Gijsselingh, de Middelburg, aqui aportados em 1633 .

A chegada dêstes novos conselheiros, homens hábeis e experimentados, fortaleceu o poder civil, deixado de lado pràticamente pelos chées militares. Além disto, circunstâncias várias, como a traição de Calabar, concorreram para que os holandeses firmassem o seu poderio nas Capitanias de Pernambuco, Itamarati, Paraíba e Rio Grande.

A situação melhora. Ceulen e Gijsselingh resolvem, então, regressar à Holanda, após dois anos de permanência no Brasil.

Após seu embarque, voltam as coisas a ser como tinham sido antes. Waerdenburch regressara à Europa em 1633, mas os chefes militares seùs substitutos eram tão hostis, quanto êle, à ingerência dos civis nas decisões de guerra. Tal ingerência, no entretanto, estava nos planos da Companhia, receosa de possibilitar aos comandantes de tropas, a oportunidade de se transformarem em senhores da terra, bem como interessada em que, em cada decisão, houvesse alguém capaz de pesar as vantagens econômicas da mesma.

Depois da partida de Ceulen e Gijsselingh diz Watjen - "os cinco membros do Conselho Político restantes ficaram às tontas. Negócios que só poderiam ser resolvidos com acerto por homens dotados de comprovado tino de organização, foram deixados à mercê de cinco Conselheiros, inexpertos, pouco zelosos, e que punham o proveito próprio acima dos interesses da Companhia. A um dos 
mesmos cabia o encargo de acompanhar o Comandante das tropas em suas expedições de guerra e assistir aos assedios, para que Schkopp e Artichofsky nenhuma ação de importancia tentassem sem consulta prévia ao Conselho Político. O segundo membro do Conselho cuidava, no Sul de Pernambuco, do armasenamento e transporte do assucar apresado, bem como do abastecimento das forças em operações nessa região. Os outros três se repartiam na Administração das quatro Capitanias conquistadas. Todos os cinco Conselheiros se achavam tão sobrecarregados de trabalho, que, mesmo por força do afastamento em que viviam, só em ocasiões de excepcional importância, se podiam reunîr em sessão em Recife". (8). Foram logo deixados de lado, pelos chefes militares. E. como eram poucos e incompetentes permitiram que a situação da colônia por si só clamasse pela substituição do sistema administrativo adotado.

WATJEN afirma que é difícil escrever a história da administração da Nova Holanda durante êste período, "pois faltam muitas peças construtivas para os anos de 1630 a 1636” (9). Já José Antonio Gonçalves de Mello Neto pensa de modo diferente: "a coleção Dagelijksche Notulen constitui um repositório de dados a que poucas épocas da vida colonial brasileira podem se equiparar em riqueza de documentação. Se se disser que aí estão referidos, dia por dia, tôdas as questões levadas à decisão do Conselho Político, a princípio (1630-1636), do Alto e Secreto Conselho (1637-1646) e do Governo Supremo (1647-1654) compreender-se-á a importância dessa coleção de Mss. Todos os problemas administrativos, políticos, sociais, econômicos, urbanos, que eram trazidos à presença do Conselho - que dirigia todo o Brasil holandês - aí estão referidos e podese ler a deliberação tomada sôbre cada um dêles". (10).

(8) O. b. cit., p. 297.

(9) O. b. cit., p. 292.

(10) José Antônio Gongalves de Mello Neto, Tempo dos Flamengos, p. 22. 
Infelizmente, os dados relativos ao direito por ventura existentes em tão importantes documentos não nos chegaram ao conhecimento.

Sabemos que "a administração da justiça achava-se entregue precipuamente ao bom arbítrio do Governador e do Conselho. A êles competia lançar os alicerces para a ereção em Pernambuco, dos institutos da administração e justiça tendentes ao fortalecimento do domínio holandez (11). Sabemos que existiam tambèm "magistrados inferiores com jurisdição no civil e no crime" (12). Ignoramos, porém, como agiram êstes magistrados, "bem como os primeiros conselheiros se desempenharam dêsse dever e quantas vêzes assumiram as funções de juiz em matéria civil e criminal". (13).

Durante o govêrno de Nassau — Já a situação muda quanto ao período do govêrno de Nassau.

Podemos ter uma idéia quase perfeita da organização judiciária estabelecida naquela época e, às vêzes, chegamos mesmo a conhecer os prédios em que se reuniam os magistrados para decidir as questões levadas a seu conhecimento.

O governador - O Poder mais alto da Nova Holanda se concentrava na pessoa. do "Gouverneur - Capiteyen ende Amiral - Generall" (Governador - Capitão e Almirante Geral). Representava a W.I. C. e chefiava o Alto Govêrno "sôbre as terras conquistadas e por conquistar no Brasil norte" (14). Trazia amplos poderes.

Era, ao mesmo tempo, chefe religioso, civil e militar. Tinha o direito de perdoar os criminosos ou de comutarlhes as penas, e desta faculdade Nassau usou com freqüên-: cia, "que era benigno de natureza", segundo refere. FreI

(11), (13) e (14) Herman. Watjen, Ob. Cit., pgs. 293, 293 e 298, respectivamente.

(12) Texto n. 45, em anexo. 
Manuel Calado - (15). Cabia-lhe nomear, consultada uma. lista fornecida pelos eleitores, os escabinos, juizes de primeira instância. (16). Competia-lhe punir os militares que se houvessem conduzido, nos combates, com covardia, pusilanimidade, ou prouca diligência. Tinha autoridade suficiente, para mesmo sem autorização expressa da Companhia, criar, junto ao Conselho de Justiça, um lugar de"Advocaat-Fiskaal" ou Promotor Público (17). Presidia ao Alto Conselho secreto. Possuía "o direito de nomeação dos. comandantes de fortalezas de regimentos militares. Era de sua competência prover todos os postos de oficiais. de alferes para cima; apenas a escolha do "Almirante da Costa Brasileira" dependia da aprovaçāo do Conselho dos XIX Devia o Diretório Geral ser igualmente ouvido se a dila. tação do território conquistado exigisse a criação de novo postos administrativos, ou fiosse necessário aumentar os salários" (18). Nas reuniões do Conselho - composto dêle e de mais três membros -- possuia dois votos, de modoque bastava ter a seu favor um dos conselheiros para fazer predominar sua vontade.

A Maurício de Nassau tratavam os habitantes da Nova Holanda por Príncipe e Vossa Excelência, embora, no dizer de Frei Manuel Calado, de jure, não tivesse mais que $S \rho$ nhoria (19), ainda que os portuguêses estivem dispostos a tratá-lo até por Eminência, Alteza e Majestade, se entendessem nisso lhe dar gôsto...

Morava nas melhores casas da cidade. Nassau, logo ao chegar, foi residir numa casa sobradada, em Antônio. Vaz, fronteira à ponte que vai para o Recife, "com varan-. das de tábuas pela fronteira de pedra e cal, obra portu-

(15) e (19) Ob. cit., pgs. 106 e 245 respectivamente.

(16) José Antônio Gonģaves de Mello Neto, Ob. cit., p. 71, nota 102.

(17) e (18) Hermann . Watjen, Ob. cit., pgs. 302 e 298 res-pectivamente. 
guesa e antiga" (20). Depois, mandou construir dois palácios, em Antônio Vaz: "um onde assistia continuadamente e outro, como local de repouso, um pouco afastado da agitação da capital; um, o Vrijburg, verdadeiramente dominador, parecendo querer imprimir no espírito dos da terra a convicção de firmeza com que os conquistadores fixaram pé na colônia portuguêsa; o outro, mais acolhedor, parecendo receber holandeses e brasileiros com espírito de igualdade" (21). E a primitiva casa do Conde tra tão boa que mal êle a abandonou, para ela se quiseram mudar os do Conselho Político, bem como os membros da Câmara de Escabinos de Maurícia - e êstes possuíam casa própria (22). Basta dizer que a verba destinada ao pagamento do aluguel do prédio de residência do governador holandês subia a 12.000 florins por ano (23), enquanto o salário mensal de cada um dos três membros do Alto Conselho fôra fixado em 800 florins (24).

O governador assemelhava-se a um soberano. Era o chefe de um principado, sugere Barleu (25). A êle, com justeza, aplicou WatJen as palavras com que François Valenti; se referiu ao governador geral da Btávia: "O poder dêste Senhor muito se aproxima ao de um rei ou monarca. Apesar de ser simplesmente o presidente do Conselho, certo é que sabe manter presos aos seus cordeis os membros do mesmo, de modo a fazer que predomine sempre a sua vontade. Mas mesmo sem tais cordeis, o seu poder é tão grande que caso tivesse de emitir a sua opinião, simplesmente como homem, nenhum dos Senhores Conselheiros teria a lembrança de contradizê-lo e se um dêles o fizesse, o Governador logo o converteria, não só a êle, como aos que o acompanhassem. Ainda na hipótese de se unirem todos contra êle não era o caso de

(20), (21), (22) e (23) José Antônio Gonçalves de Mello NETo, ob. cit., pgs. 95, 116, 118 e 118 nota 230 respectivamente.

(24) Hermann Watjen, Ob. cit., p. 308.

(25) Gaspar Barleu, Ob. cit., p. 342. Texto n. 56 em anexo. 
se dar por vencido, pois assumiria sozinho perante o Diretório tôda a responsabilidade, pelo caso em questão, e isso seria o bastante para assegurar a sua completa vitória final". (26).

Na realidade Nassau era o presidente do Alto Conselho, mas sua figura ofuscava a própria corporação a que pertencia.

Colégio do Alto Conselho Secreto - Ao lado do Governador, foi estabelecido o "Colégio do Alto Conselho Secreto", composto de três membros, diretores da W.I. C., escolhidos pela direção da Companhia, com aprovação dos Altos Poderes e do Príncipe Frederico Henrique de Orange. Os membros do Alto Conselho tinham direito ao tratamento de "Nobres, Honrados, Sábios, Piedosos, Leais" (27). Deviam servir como conselheiros do Príncipe e seus eventuais substitutos. Um dêles acompanharia sempre João Maurício nas expedições militares, pelos mesmos motivos pelos quais um dos Conselheiros Políticos deveria assessorar os chefes militares na primeira fase da conquista. "A fiscalização suprema (die Oberste kontrolle) dos negócios judiciários e financeiros da Colônia foi confiada aos Altos Conselheiros Secretos, os quaes deviam ser mantidos pelas administrações provinciais e autoridades locais ao corrente de tudo quanto se passava nas diferentes circunscrições" (28). 0 "supremo Conselho era como a Mesa do Paço, aonde presidia o Principe com os da bolsa da Companhia", diz Frei Mandel Calado (29), a última instância judiciária do Brasil holandês.

Da leitura rápida que nos foi possivel fazer de trechos do livro de Barleu ficou-nos a impressão da existência de dois Conselhos, um mais amplo, o Supremo Conselho, e outro mais reduzido, composto de membros do primeiro

(26) e (28) Hermann Watjen, Ob. cit., pgs. 300 e 299 respectivamente.

(27) José Ántônio Gonçalves de Melio Neto, Ob. Cit., p. 24.

(29) Ob. Cit., p. 146, 1.0 volume. 
e denominado Conselho Secreto: competia ao Conde "presidir ao Supremo Conselho e ao Conselho Secreto"; (30); "foram dados a Nassau para o seu conselho secreto alguns dos Conselheiros, três ou quatro escolhidos pelo Conselho Supremo e Secreto. Eles deliberariam em comum com o governador" (31). Sucede, entretanto, que WATJEN escreveu depois de BARLEU e tendo conhecimento dos trabalhos do mesmo, bem como de muitas outras obras e documentos. Assim, sua opinião, deve prevalecer e a ela nos ativemos ao dar a composição e as funções do Alto Conselho.

Segundo narra BARleU, Nassau "ideou para cada província o seu próprio brasão; depois formou o do Conselho Supremo, abrangendo num so escudo as insignias de cada uma delas, para indicar, assim, os términos do Brasil. Sôbre êste escudo viam-se as armas das Provincias Unidas e em baixo a divisa da Companhia das Índias Ocidentais" (32). Com êste escudo era feito o sêlo do Conselho Supremo.

Dispunha o Alto Conselho de um corpo de tuncionarios: o assessor, os escriturários, e um mensageiro. Segundo informa WATJEN eram os seguintes os salários mensais dos membros e dos funcionários do Alto Conselho: o Presidente: 1.350 florins; cada um dos membros: 800 florins; o assessor: 200 florins; 0 1. ${ }^{\circ}$ escriturário: 100 florins; o mensageiro: 50 florins.

Duas vêzes por semana, o Conselho Supremo dava audiência aos moradores de Nova Holanda. (33).

Conselho Político - Logo abaixo do Alto Conselho, vinha o Conselho Político, "tambem chamado Senado Político e Conselho de Justiça aonde se ia por apelação" (34)

(30) e (31) Gaspar Barleu, Ob, cit., ps. 342 e seguintes. Texto n. $56 \mathrm{em}$ anexo.

(32) Id. Ib., p. 111.

(33) Id. Ib., p. 56.

(34) e (35) Frei Manuel Calado, Ob. cit., p. 146, 1.0 volume. 
das decisões dos escabinos e era "como se fosse casa da Suplicação" (35). Este é o mesmo Conselho Político, ao qual fôra entregue, inicialmente, o govêrno da Nova Holanda.: Depois da vinda de Nassau, de acôrdo com instruções por êle trazidas da Europa, foi o Conselho transformado num tribunal de justiça, para o civil e para o crime. Seus membros em número de 9 , flamengos todos, eram nomeados na Holanda, sendo 4 de Amsterdam, 2 de Zelândia, 1 para cada uma das três circunscrições do Mosa, do Norte e Groninga. Dos nove membros, 5 deviam permanecer sempre na sede do govêrno e os outros 4 "se encarregariam da administração provincial, mas depois de algum tempo revesar-se-iam com os colegas investidos em funções judiciárias na capital" (36). Já em 1639 sobe a 11 membros; mais tarde a 13 e 17.

O sêlo do Conselho de Justiça, também ideado por Nassau, era constituído pelos brasões das quatro províncias, contidos num escudo semelhante sôbre o qual se via a Virgem Astreia, trazendo numa das mãos a espada, vingadora dos crimes, e na outra uma balança, regra dos comerciante (37).

O pessoal do Conselho político era mais numeroso do que o do Alto Conselho. Vejamos o quadro dos salários mensais pagos pelo tribunal de segunda instância da Nova Holanda: cada conselheiro: 300 florins; o secretário: 90 florins; o Promotor Público: 156 florins; o escriturário: 50 florins; o auditor: 40; o $1 .^{\circ}$ oficial: 65 ; o $2 .^{\circ}$ oficial: 20 ; o carrasco: 52; o ajudante: 15; o servente do Conselho 15 (38).

Segundo parece, pelo aumento do número de seus membros era muito o trabalho a ser realizado pelo Conselho de Justiça. Houve mesmo a necessidade de impedir

(36) Hermatn WatJen, Ob. cit., ps. 301 e 303. Texto n. 56 em anexo.

(37) Gaspar Barleu, Ob. cit., p. 111.

(38) Hermann Watjen, Ob. cit., p. 308. 
certas apelaçôes: "para não aumentar excessivamente para os juizes superiores a tarefa das causas forenses, vedaramse as apelações đe menor importância." (39).

Formava o Conselho Político a segunda instância, em relação aos tribunais de escabinos.

Mas tinha também competênciā originária. Durante o tempo em que se discutiu se a Câmara de Escabinos de Olinda devia permanecer na velha capital ou ser transferida para Recife ou Antônio Vaz, os moradores destas tinham o direito de escolher entre a propositura de suas demandas perante os escabinos de Olinda ou diretamente ao Conselho Político, sediado no Recife, renunciando assim a uma instância. Além disto, o julgamento de certos crimes parece ter sido de sua originária competência, como o do delito de blasfêmia, segundo se infere de um protesto da Comunidade Israelita da Holanda contra perseguições a judeus em Pernambuco; queixava-se a comunidade de que "os escabinos de Maurícia, em vez de entregarem ao Conselho de Justiça o julgamento (de determinado caso), avocavam ilegalmente ao seu fôro os delitos por blasfêmia" (40).

O Conselho Político teve, inicialmente, como sede a cidade de Olinda, sendo que uma das primeiras cartas escritas de Olinda pelo secretário do Conselho Político ao Conselho dos XIX, em 2 de abril de 1630, foi datada do Convento dos Jesuítas. (41). Não tardou, porém, que $o$ Conselho Político, antes mesmo da destruição de Olinda, se transferisse para Recife ou Antônio Vaz, pois destas İocalidades foram datadas cartas enviadas a Holanda, a partir de 4 de outubro de 1630 (\$2). Sabemos que, na cidade do Recife, os conselheiros políticos Carpentier e

(39) Gaspar Barleu, Ob. cit., p. 75.

(40) Hermalnin WatJen, Ob. cit., p. 369.

(41) José Antônio Gongalyes de Mello Neto, Ob. Cit., p. 44.

(42), (43), (44) e (45) José Antônio Goinģalves de Mello: NETo, Ob. cit., p.gs. 51, 53, 62, 62 respectivamente. 
Walbeeck possuíam verdadeiros palacetes como residência (43), mas sôbre as casas ocupadas pelo Conselho até 1636 , não obtivemos dados. Naquele ano decidiram os conselheiros construir a Casa da Câmara. "Para isso resolveram aproveitar, melhorando-a, a casa em que morava o subchefe da equipagem e alguns marinheiros", preparando-se uma boa sala do Conselho e, do Tado sul, sala para a secretaria, tesouraria e para uma futura contadoria geral". Isso, no primeiro andar, pois a parte baixa, ou térrea, deveria ser transformada "em cadeia para gente criminosa". A parte superior do Conselho seria reservada para um "bom miradouro" ("beuquaem uijsicht") e para o alojamento dos empregados e chefes da secretaria e tesouraria" (44). A resolução do Conselho foi tomada considerando, segundo informação dos próprios conselheiros à metrópole, “o grande inconveniente que advém da falta de um lugar apropriado no qual se possam realizar as reuniões, com decência, para, afastados do ruído e da movimentação do todo o mundo, tomar boas resoluções de que necessitam os negócios do govêrno e a boa ordem destas terras do Brasil e sendo considerado ainda que, para desreputação do mesmo Conselho, nenhuma ordem pode atualmente ser suficientemente mantida na condução dos negócios e expedientes e que, por isso, é muitíssimo necessário escolher um local para a construção de um importante ("solemnel") e bem construída Casa do Conselho" (45). Esta casa, a "Raethuys" ficava vizinha da igreja do Corpo Santo e, segundo indica o mapa reproduzido em seu livro por José Antônio Gonģalves de Mello Neto (46), ocupava todo um quarteirão, fronteiro ao mar. O edifício veiu a ruir anos depois, talvez em 1641, pois, em 1642 foi enviada à Holanda "a planta da nova casa do Conselho, como nos parece que deve ser construída, de modo a ter reunido em um só local toda a direção dos negócios da Companhia"

(46) Ob. cit., p. 130. 
(47). Foi por esta época, maio de 1642, que o Conselho Político pretendeu ocupar a primitiva casa de residência do Conde de Nassau. Se realizou, ou não os seus planos - quer de mudança, quer de construção - foi o que não pudemos apurar.

Logo abaixo do Conselho de Justiça, vinham, na ordem de hierarquia judiciária, os Conselhos dos Escabinos, criados por Nassau, de acôrdo com instruções trazidäs da Holanda.

Escabinos - Estes Conselhos eram tribunais colegiados, aos quais pertenciam holandeses e habitantes das terras ocupadas. Foram constituídos conselhos de escabinos com holandeses e portuguêses. Não temos elementos para aifrmar a existência de Câmara de Escabinos compostas de holandeses e indios, embora possam talvez induzir a isto as seguintes transcrições de trechos do livro de José Antônio Gonçalves de Mello Neto:

"Para acomodar os índios e "evitar as consequência do massacre de holandeses que teve lugar no Ceará, obra de índios revoltados, no ano de 1644, o Conselho dos XIX reconheceu em documento escrito - "por provissão", dizem os Mss. - o direito dos indios, tupis e tapuais, à liberdade. $O$ documento se achava em poder dos índios em 30 de março de 1645, quando teve lugar na aldeia de Tapiserica a grande reunião de indigenas para a qual Souto Maior foi o primeiro à chamar a atenção, traduzindo para o português o que consta de certa Dagelijksche Notule. Nessa ocasião foram escolhidos regentes índios para dirigir grupos de aldeias, bem como instituidas Câmaras de Escabinos para cada um dêsses grupos. Às câmaras cabia dirigi-los, sendo que as

(47) José Antônio Gonģalves de Mello Neto, Ob. cit., p. 62 , nota 83 . 
resoluções de caráter geral deveriam ser tomadas depois de ouvidos o "commandeur" John Listry e o Supremo Conselho" (48).

Os regentes foram Antônio Paraupaba (aldeias do Rio Grande), Pedro Poti (aldeias da Paraíba) e Domingos Fernandes Carapeba (aldeias de Goiana e Itamaracá): Dag. Notule de 11 de abril de 1645. Pouco antes os índios haviam pretendido nomear para governá-los um rei, isentando-se da sujeição de capitães e "comandeurs" holandeses; Antônio Parupaba que acabava de voltar da Holanda assegurou aos Supremos Conselheiros que o pensamento do Conselho dos XIX era que "holandêz algum os governasse, mas que escolhessem entre os seus um chefe"; e o Conselho com jeito obteve que escolhessem não um chefe único, mas três regentes, um para cada Capitania, para governá-los, os quais deliberariam com a assistência do "commandeur" Listry: Gen. Missive ao Conselho dos XIX, datada do Recife, 27 de junho de 1645" (49).

Focalizada esta hipótese da possibilidade de uma justiça colegiada da qual participassem holandeses e índios, passemos a analisar a organização dos tribunais de escabinos holandeses e portuguêses.

Os Conselhos de Escabinos erám tribunais munícipais com jurisdição civil e criminal. Já vimos que o Conselho de Justiça, o Conselho Político, reservava para si o conhecimento originário de certas questões jurídicas. Qual a competência exata dos escabinos não nos foi possível conhecer. Antônio Gonçalves de Mello Neto diz que "a alçada dessas Câmaras atingia os papeis civis e criminais

(48) e (49) Tempo dos Flamengos, ps. 247 e 247 nota 36. 
em primeira instância, podendo multar até 120 floris". (50).

Os escabinos eram escolhidos dentre os habitantes da terra, e, de certo modo, pelos próprios habitantes. Assim descreve José Antônio Gonçalves de Mello Neto o processo de uma seleção de escabinos: "o escolteto, no Recife, ou o diretor nas demais Capitanias conquistadas, selecionava certo número de pessoas, tanto holandeses como brasileiros: eram os chamados eleitores. Èsses eleitores, em sessão, indicavam vários nomes dentre os seus, os quais, em uma lista, eram submetidos à apreciação de Nassau (e, depois de 1644, à junta que o substituiu) que fazia a designação para o cargo de escabino. Esses escabinos eram substituídos anualmente" (51).

Os escabinos não tinham apenas função judicante. Eram assistentes do Esculteto, o chefe administrativo do municipio, e com êle formavam o Conselho Comunal. Preocupavam-se com os problemas administrativos e participavam do govêrno do município. O Conselho Político queixou-se, por mais de uma vez, ao XIX da Companhia contra "a atitude provocante que a seu respeito haviam assumido os "Escultetos e Escabinos de Maurícia" (Schout en Scnepenen van Mauricia). E Nassau também fêz sentir à Direção da Companhia o inconveniente de ampliar as competências dos escabinos e escultetos (52).

Sendo um tribunal composto de flamengos e portuguêses, qual a língua usada nas Câmaras de Escabinos? Deixemos falar Frei Manuel Calado: "A pessoa que nestes Conselhos queria pôr alguma coisa, primeiramente havia de dar meia pataca para the receber a petição, e as petições, e auções que faziam, forçosamente para se lhe deferir as haviam de levar escritas em lingua Flamenga, e para isso (suposto que os mais dos ministros entendiam,

(50) e (51) Ob. cit., pgs. 137-138.

(52) HermanN WatJen, Ob. cit., p. 307. 
e falavam lingua Portguesa) tinham ordenado certos oficiais, os quais transladavam as petições dos Portgueses em Flamengo, e levavam por cada uma pataca". (53). Noutra passagem, assim se refere Frei Manuel Calado ao problema da língua a ser usada nos Colégios de Escabinos: "quando os escabinos Portugueses se ajuntavam todos, se punham os Flamengos a falar uns com os outros na sua língua e davam o despacho como lhes parecia, e o punham diante dos Escabinos Portugueses, os quais por fôrça, ou por grado assinavam o que os Flamengos queriam. $O$ que vendo João Fernandes Vieira, que foi eleito escabino, à primeira vez lhe pareceu mau aquele modo de despachar, e à segunda disse, que para pôr o seu sinal the haviam de ler primeiro em lingua portuguesa a demanda, e o despacho dos Holandeses, porque não havia de assinar sentença que nâo fosse muito justa; e da terceira vez, ou quarta, prometeu de nâo se ajuntar mais em Conselho". (54).

Nassau foi incumbido de fixar tribunais desta natureza nos lugares mais importantes da Nova Holanda. Em janeiro de 1638 já existiam seis colégios de escabinos em pleno funcionamento; com cinco membros, os de Olinda, Itamaracá e Paraíba; com três membros, os de Iguarassu, Serinhaem e Paraíba. Com o correr dos tempos, outros. foram fundados, quer pelo desdobramento dos primitivos, quer pela conquista de novas regiões.

As informações mais completas que conseguimos se referem ao Colégio de Escabinos de Olinda. Sua jurisdição. iniciava-se no rio Jaguaribe e ia terminar no rio Serinhaém, ao sul, incluindo, assim, Olinda, Recife e Antônio Vaz. Foi composto, a princípio, de 5 membros e, mais tarde, de 9. Tinha como sede a cidade de Olinda, o que fêz surgir um grave problema de competência: os habitantes do Recife e de Antốnio Vaz desejavam decidir seus pleitos perante o Conselho Político, sediado em Recife, com o que

(53) e (54) Ob. cit., ps. 289 e 147, respectivamente, ambas do $1 .^{\circ}$ volume. 
não concordavam os escabinos de Olinda. A êles cabia o julgamento dos pleitos em primeira instância. Os Nobres Senhores Conselheiros Politicos, com isto estavam em desacôrdo sustentando que "os moradores (de Recife e Antônio Vaz) estão subordinados não aos Escabinos, mas diretamente ao seu colégio e a ninguém mais, procurando basear isto no art. 27 das Instruções Gerais, alegando, que não há razão alguma para que os moradores de Recife que no Recife podem ter decisão de seus pleitos - com grandes gastos, às vezes em processos de pequena importância, com perda do seu tempo e dos seus negócios, necessitem ir a Olinda para acompanhar as suas causas". (55). Além do mais, o Conselho Polítíco considerava um desprestígio a existência de outro tribunal onde estivesse êle sediado (56): Por sua vez, os moradores do Recife desejavam ter o seu próprio tribunal para não ficarem em condição de inferioridade com os burgueses de Olinda e outros municípios. A decisão do caso foi entregue ao Conselho dos XIX e êste mandou transferir a Câmara de Escabinos de Olinda, para Antônio Vaz, o que foi feito em 14 de novembro de 1639. Mesmo em Antônio Vaz, os escabinos continuaram a usar o título de "Escabinos de Olinda", até que Gaspar Dias Ferreira - português a respeito de cujo caráter o Padre Frei Manuel Calado diz as piores coisas - pediu autorização ao Conde e ao Alto Conselho para adotarem a denominação de "Escabinos da Cidade Maurícia e seu distrito", o que foi autorizado no dia 23 de dezembro de 1639.

Pelos nomes de seus primeiros membros - Wilhenlm Doncker, Jacques Hack, Francisco de Brito Pereira, Gaspar Dias Ferreira e João Carneiro de Mariz - parece que, na primeira Câmara de Escabinos de Olinda eram três portuguêses para dois holandeses. Se tal ocorreu foi logo

(55) e (56) José Antônio Gongalves de Mello Neto, Ob. cit., ps. 73-74, nota 105 . 
corrigido, passando os holandeses a contar sempre com um membro a mais do que os portuguêses.

"Interessantíssimo" - diz Gonçaldves de Mello "seria encontrar as "Notulen" das Câmaras de Escabinos, fundadas no mesmo ano de sua chegada pelo Conde de Nassau; há informações oficiais de que eram redigidos e era determinação superior que extratos deviam ser enviados regularmente, de 3 em 3 meses, ao Conselho dos XIX (Dag. Notulen, de 19 de novembro de 1641, 14 de agosto e 18 de dezembro de 1642, etc.) Nem José Higno nem Watjen a elas se referem" (57).

Falta-nos, assim, uma fonte preciosa, talvez a única, que nos permitisse conhecer minuciosamente as questōes jurídicas levadas ao conhecimento dos Escabinos.

De Olinda, o Colégio se transferiu para a cidade Maurícia e se estabeleceu em prédio próprio, adquirido de Pieter Bonjour, mordomo de Nassau. Mais tarde, pleitearam os escabinos mudar-se para a primitiva casa do Conde, tendo-lhes sido concedido o direito de ocupar a frente da referida residência. "Não podemos afirmar que se tenham mudado pois, em 22 de janeiro do mesmo ano (1643) deram ciência ao Alto Conselho que o antigo paço estava tão arruinado que sem reparaçốes não podiam ocupá-lo, tendo os Conselheiros se recúsado a auxiliá-las" (58). WatJen, porém, informa que o escabinos se reuniam na Casa da Câmara da Cidade Maurícia, talvez a mesma cuja construção pleiteou o Conselho Político.

$O$ escolteto, de tão grande influência na escolha dos escabinos, era, segundo, uns uma espécie de burgomestre. WATJEn informa ser êle mais do que isto, pois era igualmente "Promotor de Justiça, Exator da Fazenda e Chefe de Polícia, em sua respectiva circunscrição."

Ministério Público - Qual seria a organização do Ministério Público, no Brasil holandês?

(57) Ob. cit.,

(58) Ob. cit., p. 118, nota 230. 
Comecemos pela primeira instância, pelas Câmaras de Escabinos. Eram elas presididas pelos escoltetos, os quais além das funções de presidência do colégio dos magistrados de primeira instância, exerciam muitas outras. Ao esculteto, assim se refere PôRTo Sequro, em sua História das Lutas com os Holandeses no Brasil: "O esculteto era a autoridade executiva, ou delegado da administração e promotor público do lugar; e ao mesmo tempo exator da fazenda". (59).

BARLEU, ao se referir à justiça de primeira instância declara: "Cada uma das províncias tem também a sua magistratura que exerce jurisdição sôbre as cidades e as vilas do seu território. Os membros delas chamadas eleitores e escabinos desempenham função temporária e não remunerada. Perante êste servem o cargo de promotores públicos, não sem autoridade, aqueles que se chamam escultetos, pretores ou balios" (no estudo feito à página 342 e seguintes, sôbre a organização do govêrno da Nova Holanda, em sua História dos feitos de Nassau). Gonģalves dE Mello Neto diz que o esculteto era "uma espécie de burgo-mestre" (60). E WATJEN, depois de afirmar que o esculteto era o chefe administrativo do Municipio, esclarece que êle "não exercia sòmente as funções de seu cargo, pois, era igualmente Promotor de Justiça, Exator da Fazenda e Chefe de Polícía em sua respectiva circunscrição" (61). Além disto, cabia ao escolteto indicar, dentre os seus jurisdicionados, aquêles que, como eleitores, deveriam escolher os escabinos da Câmara local. Se as funções dos escabinos não eram remuneradas, como pretende Barleu, as do esculteto o eram; pelo menos cabiam a êle comissões ou percentagens sôbre as multas e penas pecuniárias impostas. Frei Manuel Calado se revolta com a

(59) p. 177.

(60) José Antônio Gonghalves de Mello Neto, Ob. cit., 171.

(61) HermanN Watjen, Ob. cit., p. 305. 
ganância destes "leões vorazes" (62) e a êles e a suas falcatruas dedica páginas e páginas de seu livro (63): “...saiam seus Escoltetos cada seis meses pelos campos, e matos, com outros ministros da justiça; e chegavam às casas dos moradores, e nenhum havia que não ficasse condenado em dinheiro, ainda que tivesse feito milagre no cumprimento de suas premáticas; e os Escoltetos todas as condenações que faziam eram para si, e dali davam ametade aos do Conselho, segundo suas diabólicas mancomunações, e como os Escoltetos condenavam sem apelação, nem agravo, para outro superior, alargavam a mão, e a boa vontade, segundo lhes parecia". Não menos veemente é a linguagem usada pelo próprio Nassau, em seu testamento político, sôbre os escultetos: “o remédio para isso (exploração dos escultetos) será abolirem-se as penas dos delitos leves e várias leis, salvas aquelas com as quais se repunem os crimes graves. Privados assim êstes grilos e sanguesugas dos nomes de tantas multas, se escravizariam menos a sua insaciável cobiça. Além disso conviria entregar estas funções sòmente aos mais conceituados, afastando-se delas os ladrões que, como Gueirões, vão arrebatar o alheio com seis mãos". (64).

Tinha, assim, o esculteto funções de Promotor Público, reunidas a outras de diversas natureza.

Ainda na primeira instância, existiam os Curadores. Para cada circunscrição municipal foram nomeados "três curadores (Waisenmeiter), dous Portuguezes e um Holandez, encarregados de amparar os menores órfãos. Da necessidade deses funcionarios convencem as repetidas tentativas, frequentamente bem sucedidas, de indivíduos sem consciiência para se apoderarem das heranças das crianças orfanadas" (65).

(62) e (63) Ob. cit., 298 e 295 e seguintes, respectivamente.

(64) Gaspar Barleu, Ob. cit., p. 33.

(65) Hermann Watjen, Ob. cit., ps. 305-306. 
Este o Ministério Público de primeira instância no. Brasil holandês: escultetos (em suas funções de Promotor de Justiça) e curadores.

Vejamos, agora, na segunda instância. Perante o Conselho de Justiça funcionava um Fiscal, segundo dá notícias no seu Iivro Frei Manuel Calado (66). Este fiscal, Advocaat-Fiskaal era o Promotor Público, perante os Conselheiros Políticos. "Conquanto" - diz WarJen - "nas Instruções de 23 de Agosto de 1636" (as que Nassau trouxe da Holanda), não se houvesse cogitado de um lugar de "Advocaat-Fiskaal", ou Promotor Público, logo após a chegada de João Maurício, o conselheiro político De Ridder foi nomeado para exercer as funções dêsse novo cargo junto ao Conselho de Justiça. Até onde se extendiam os seus poderes e que outras funções além das suas primitivas porventura desempenhava, não se pode mais determinar. O material manuscrito é inteiramente mudo a êsse respeito. Segundo toda aparência, de Ridder aceitou o cargo muito a contra-gôsto. Faltava-lhe todo conhecimento prático, e apenas algumas semanas depois de sua investidura, Gijsselingh assim se manifestava a seu respeito: "Em vez de cumprir como Advogado-Fiscal o seu dever para com o. Govêrno e a Companhia, de Ridder prefere dedicar-se à fabricação do assucar, conquanto a promotoria the pudesse proporcionar belos lucros". O pedido de exoneração dêsse funcionário teve de seguir os seus trâmites, e largo tempo se passou antes que se desse a sua desejada substituição por um holandês competente em matéria de jurisprudência". (67)

Deveria caber ao Advocaat-Fiskaal as funções de defensor dos interêsses da Companhia, nas causas civeis e fiscais da competência do Conselho, bem como a missão de acusar os criminosos autores de delitos cujo julgamento estivesse entregue, originàriamente, à segunda instância.

(66) Ob. cit., p. 139

(67) Hermann Watjen, Ob. cit., ps. 302-303. 
Possivelmente, cabia-lhe também manifestar-se sôbre apelações das sentenças dos escabinos.

Existiria um Ministério Público de terceira instância, perante o Alto Conselho? Ou as funções de defender os interêsses da Companhia, de apontar à justiça os delinqüentes e de aplicar a justiça se reuniriam no Governador? Quem acusaria os criminosos autores de fatos da competência originària do Supremo Conselho? Quem defenderia os interêsses da Justiça e dos órfãos nas apelações chegadas ao Conselho Supremo? Foi o que não conseguimos apurar.

Possivelmente tambẻm não havia uma organização interna do Ministério Público, uma carreira estruturada. Nada ligava os escultetos entre si, como Promotores Públicos, nem os escultetos ao Advocaat-Fiskaal. Mas todos estavam subordinados ao Governador.

Esta a organização judiciária da Nova Holanda.

Acima dela estavam a Companhia e os Estados Gerais e o Príncipe de Orange.

BARLEU situa muito bem o problema: "Todo êste império do Brasil é parte das Provincias Unidas dos países Baixos, as quais, depois de haverem declarado juridicamente deposto Felipe, rei das Espanhas, por ter violado as leis da República, não sòmente defenderam dentro de suas fronteiras o que lhes pertencia, mas ainda revidaram à Espanha a guerra que ela trouxera a êste país, e navegavam, de um lado para as últimas terras das Índias Ocidentais, mandando-lhes as armas juntamente com o comércio. Navegaram também para o Brasil, onde o ínclito valor dos batavos, apoiado pelas riquezas de uma nova companhia, fulgiu contra o mesmo inimigo que na Holanda.

A referida Companhia geriu, como sob a forma aristocrática, essa República, e, com sábios alvitres, dirigiu por intermédio do Conselho dos XIX, esse dominio estrangeiro. Não, porém, sem um principado, porquanto, suprimido ali o título de rei e vice-rei, sob cujos auspícios se governava 
antes o Estado, recebeu legitima autoridade para isso o ilustríssimo Maurício, com o título de Governador, e capitão general, com supremo poder na terra e no mar. Ratificaram esta investidura os Estados Gerais, o Príncipe de Orange e os diretores da Companhia" (68).

Príncipe de Orange, Assim, acima do Governador da Nova Holanda se encontrava a Companhia, cuja direção geral cabia ao chamado Conselho dos XIX, composto de representantes das Câmaras de Comércio formadas quando da organização da Companhia. Estas eram em número de cinco: a de Amsterdam, a de Middelburgo, a de Maasquartier (distrito do Mosa, Rotterdam, Dordrecht e Delft), a de Norderquartier (distrito Norte - Hoorn, Enkhuizen) e a de Groninga. Para a formação do Conselho dos XIX, as Câmaras concorriam com representantes, em número proporcional aos quinhões de cada uma no patrimônio da sociedade: Amsterdão, com 8, Zelândia, com 4, e as outras. com 2, cada uma. O décimo-nono diretor era nomeado pelos Estados Gerais, aos quais tratando-se de operações de guerra da W. I. C. cabia a palavra decisiva" (69).

Estados Gerais e Conselho dos XIX - Segundo GonGALVES DE Mello, "havia um protocolo complicado para o tratamento dos vários membros do governo, oficiais, etc. Os Estados Gerais eram chamados "Muito Poderosos Senhores", os membros do Conselho dos XIX tinham direito ao tratamento de "Honrados, Prudentes e muito discretos Senhores". (70)

Já nos referimos ao conflito de jurisdiçąo surgidio entre a Câmara de Escabinos de Olinda e o Conselho Político. $\mathrm{O}$ Governador e o Alto Conselho não decidiram o problema, mas o encaminharam para os XIX: "como se trata de um ponto de justiça e que só pode ser decidido

(68) Gaspar Barleu, Ob. cit., p. 342.

(69) Hermann Watjen, Ob. cit., p. 79.

(70) José Aintônio Gonģalves de Mello Neto, Ob. cit., p. 24, nota 6 . 
pela autoridade soberana não quisemos entrar na questão; resolvemos deixá-la como estáva até que tendo submetido - caso à vossa aprecỉação, VV. SSas. quisessem dispor a respeito no vosso alto entender e sôbre isso esperamos a vossa resposta com brevidade" (71).

Além dêste existe o caso da ponte de Antônio Vaz. Nassau resoTveu ligar Recife e Antönio Vaz por uma ponte, para cuja construção foi aberta concorrência em edital: “o serviço da ponte atualmente iniciado na passagem do Recife para a cidade Maurícia será entregue àquele que desejar tomá-lo sendo pessoa que a Sua Excelência e aos Senhores do Alto Conselho parecer capaz para tomar a dita obra e efetuả-la. As pessoas que tiverem interêsse nisso, devem na segunda feíra, dia 11 de fevereiro próximo (1641), se dirigir à chamada Casa do Alto Conselho, onde lhes será mostrađo o projeto da referida obra e juntamente as instruções e condições qưe na dita obra devem ser obedecidas e que são as abaixo com exceção das que se mencionam nas ditas instruções e projeto de obra, que podem ser vistos na casa do sr. Gaspar Dias Ferreira" (72). Venceu a concorrência Baltazar da Fonseca, que apresentou bons preços, deu garantia de imóveis e ofereceu dois fiadores dignos de confiança. Iniciada a construção em 1641, foi ela abandonada, em 1643, pelo empreiteiro. Frer Manuel Calado điz que por tramoias armadas pelos holandeses, no que é contestado por Gonçalves de Mello: (73) “"o construtor não soube levar a obra avante quando chegou ao trecho mais profundo do rio." 0 importante é que nasceu daí uma demanda e "o pleito foi mandado à Holanda", não estando ainda resolvido em 1648.

Havia, assim, na hierarquia judiciária, acima dos tribunais, da Nova Holanda, a justiça da metrópole. Não

(71) Id., Ib., p. 74, nota 105.

(72) José Ántônio Gongalves de Mello Neto, Ob. cit., p. 107.

(73) Id., Ib., p. 110. 
pudemos apurar se era possível recurso aos tribunais de justiça batavos ou apenas à direção da Companhia.

Ignoramos, também, se os recursos para a metrópole podiam ser feitos em matéria criminal e, se o podiam, dentro de que limites. Temos a impressão de que, se existiam, eram em setor muito restrito, pois nem em CaLAdo, nem em Barleu, nem em Gonģalves de Mello, nem em Watjen, encontramos nenhum caso de recurso pará a Holanda em matéria de direito penal.

Justiça Religiosa - Ao lado desta organização, os holandeses trouxeram, parece-nos, tribunais religiosos para a Nova Holanda. Afirma BARleu: "Está em uso no Brasil a mesma forma de governo eclesiástico que nas igrejas holandesas. A suprema autoridade pertence ao Conde e ao Conselho Secreto, aos quais incumbe também dirigir esta nau sacudida pelas suas ondas, atacada pelos seus inimigos, sofrendo dos seus vícios. A autoridade dos Sinodos é maior que a das Classes e a desta superior à dos Presbiteros. As decisões dos Sinodos não têm validade sem a aprovação dos diretores da Companhia" (74).

"Todos os padres protestantes que exerciam o seu ministério na Nova Holanda pertenciam como membros ordinários ao Conselho Eclesiástico Recifense, do qual também faziam parte, como deōes (Aelteste) diversos escabinos, oficiais, agricultores ou comerciantes, bem como de dois a três conselheiros políticos" (75).

Este Conselho Eclesiástico "chamou à barra de seu fôro pessoas que se haviam tornado culpadas de adultérios ou viviam amancebadas, e advertiu, sob ameaça de imediata demissão, no caso de reincidêncìa, a diversos párocos para que abandonassem a sua conduta escandalosa e voltassem ao caminho da virtude, como convinha a um servidor da palavra divina."

(76)

(74) Gaspap Barleu, Ob. cit., p. 344.

(75) HermanN WatJen, Ob. cit., p. 347.

(76) Id. Tb., ps. 348-349. 
Justiça Militar - Do mesmo modo, parece-nos ter existido uma justiça destinada a punir militares em suas faltas, subordinada porém, como as demais, à autoridade do governador.

Apreciaçâo sôbre o funcionamento da Justiça Holandesa no Brasil - Referida a estrutura judiciária do Brasil holandês, seria interessante saber como funcionou esta justiça. BARleu a elogia, com restrições. Nassau aponta seus defeitos.

Frei Manuel Calado não a perdoa. Admite qualidades no Príncipe, mas o inclui nas negociatas feitas então. Aos do Supremo Conselho, aos do Conselho Político, ao Fiscal, aos escabinos flamengos, aos escultetos, nega qualquer interêsse em fazer justiça. Tôda a organização judiciária existente outro fim não teria senão o de "dissipar e destruir a Província de Pernambuco, e parar de sorte aos moradores delas, que thes não ficasse coisa em que por os olhos, para que ou forçados da necessidade despejassem a terra, e fôssem buscar para viverem outras estranhas, ou constrangidos das muitas crueldades e traições lhes entregassem tôdas suas fazendas, e havendo de ficar na terra fôssem mais que cativos, e escravos trabalhando de dia, e de noite. não para si, senão para seus inimigos" (77). Estas afirmativas de Calado vão encontrar, de certo modo, ressonância na apreciação feita pelo Conde João Maurício de Nassau em seu testamento político: os holandeses "são homens tais que preferem sofrer dano na vida a sofrê-lo na fazenda; esta é para êles mais cara que a menina dos olhos" (78).

Depois de Nassau - Depois da volta de Nassau à metrópole, a organização judiciária da Nova Holanda começou a ruir.

(77) Frei Manuel Calado, Ob. cit., p. 288.

(78) Gaspar Barleu, Ob. cit., p. 332. 
O Iugar do governador não foi preenchido. O govêrno do pais passou ao Alto Conselho. $\mathrm{E}$, durante o periodo de sítio do Recife, aos chefes militares.

"Também o Colégio do Conselho Político foi arrastado pelo vórtice, e, no comêço da quinta década secular, - quando a administração militar da cidade do Recife, então em sítio, enfeixava nas mãos todo o poder, foi pôsto à margem rudemente pelo Comandante em Chefe das tropas" (79).

"No tempo da Revolução, os Colégios de Escabinos rapidamente se destroçaram em consequência da atitude irreconciliável de oposição entre Holandeses e Portugueses, - e mesmo a Côrte de Escabinos da cidade Maurícia, depois de 1645 , perdera inteiramente a sua importância" (80).

Assim, quando em janeiro de 1654, as tropas libertadoras entraram no Recife nada mais havia do organismo judiciário pôsto em vida pelo Conde de Nassau.

\section{3 - Legislação vigente no Brasil Holandês}

Qual o direito aplicado na Nova Holanda? O direito holandês? O direito espanhol? O direito português? Ou cada um dêstes direitos de acôrdo com a nacionalidade dos interessados?

Foi dêste tipo uma das prineiras perguntas dirigidas a Nassau, logo após a sua posse, em 1637. A Câmara de Olinda desejava saber "se seriam mantidos os privilégios concedidos pelo rei de Portugal aos senhores de engenho e se seriam regidos pelas ordenações do Reino. Ao que respondeu o Alto Conselho que indicassem (os consulentes) quais os privilégios de que gosavam e acrescentou que êles estavam subordinados aos usos, ordenações e costumes imperiais da Holanda, Zeelândia e Frisia Oriental. Idêntica consulta foi feita, também, pela Câmara da Paraíba" (81).

(79) HermanN Watjen, Ob. cit., p. 305.

(80) Ob. cit.

(81) José Antônio Gonģalves de Mello Neto, Ob. cit., ps. 159-160. 
O próprio Nassau, citado por Barleu (82) esclareceu aos portuguêses que "não poderiam viver, entre um povo inimigo dos espanhois, segundo as leis e o direito de Portugal, mas segundo as leis imperiais alemãs, as do Império Romano e as vigentes na Holanda, Zelândia e Frisia".

E ainda BARLEU quem refere: "repudiaram-se as normas do costume português, em virtude das quais se tornara firequente por éssa época resgatarem-se pecuniriamente os mais graves delitos" (83).

Vê-se assim que o direito em vigor no Brasil holandês. foi, antes de tudo, o vigente nos Países Baixos.

Ao lado dêste surgiu o criađo no novo mundo, o contido nas leis promulgadas ou emanadas pelo Alto Conselho e pelos demais poderes da colônia. Diz BARLEus: após a chegada de Nassau "restaurou-se a reverência à religião, o respeito ao Conselho, o horror dos julgamentos e o vigor das leis. Muitas foram proveitosamente emendadas e outras promulgadas" (84). E, outro trecho de seu livro: "reprimiram-se pois, em severissimos editos, os duelos restabelecendo-se contra os homicidas o rigor das leis" (85). Calado nos mostra um sem número de leis promulgadas no Novo Mundo no sentido de coibir as traições, de: tornar maiores os lucros da Companhia, de fortalecer a religião reformada.

Além disto, a própria Companhia também legislou para o Brasil. Curioso exemplo disto narra Gonģalves DE Mello. Para acomodar os índios "e evitar as consequências do massacre de holandeses que teve lugar no Ceará, obra de índios revoltados, no ano de 1644, o Conselho dos XIX reconheceu em documento escrito - por provisão dizem os. Mss. - o direito dos índios, tupis e tapuias, à liberdade"

(82) Gaspar Barleu, Ob. cit., p. 55.

(83) Id. Ib., p. 54.

(84) Gaspar Barleu, Ob. cit., p. 53.

(85) Id., Ib., p. 209. 
(86). O documento em que era proclamado tal direito "foi enviado da Holanda com a carta do Conselho dos XIX ao Alto Conselho" (87).

Assim, vigoraram no Brasil holandês as leis imperiais alemãs, as do Império Romano, as vigentes na Holanda, Zelândia e Frísia, bem como as promulgadas, depois da conquista, na metrópole e em Pernambuco para terem vigência nas terras conquistadas.

\section{4 - Dados sôbre o processo penal}

Não nos foi possível consultar a legislação que vigorou no Brasil holandês. Limitamo-nos a colhêr dados nas obras que nos pareceram fundamentais de Frei Manuel Calado, Gaspar Barleu. Hermann Watjen e José Antônio Gonçalves de Mello Neto. Não há, assim, possibilidade de um estudo minucioso do processo penal seguido no Brasil holandês. Parece-nos, todavia, ser possivel apresentar uma idéia geral do assunto.

Fase Policial e Fase Judicial - Segundo tudo indica, inexistia uma distinção nítida entre fase policial e fase judicial do processo. O esculteto é, ao mesmo tempo, chefe de polícia e promotor público, mas a acusação não é apenas pública; particulares também podem pedir aos tribunais a condenação dos delinqüentes.

Acusação Pública e Prisão Preventiva - Apontado um cidadão como autor de um delito, ou era imediatamente prêso ou livrava-se sôTto. Possivelmente esta diferença de tratamento decorria da natureza do delito. A mais leve suspeita de traição, de relações com os portuguêses inimigos, de troca de correspondêncỉa com a Bahia bastava para conduzir à prisão os acusados: "souberam logo disto os do Supremo Conselho, e cheirando-lhe a espécie de trai-

(86) e (87) José Antônio Gonçalves de Mello Neto, Ob. cit., ps. 246 e 246, nota 35 respectivamente. 
đ̧ão maudaram... aos Capitães meter em uma fortaleza para se fazer neles exame" (88). Os presos ficavam ou na cadeia pública, ou em fortalezas ou mesmo em navios surtos no pôrto. Muito dos presos nos navios eram postos em grilões, como refere Frei Manuel Calado "nesta mesma conjunção chegaram ao nosso arraial dois filhos de Antônio Gomes Salgueiro, aos quais os Holandeses haviam preso quando os moradores se levantaram com João Fernandes Vieira, e aclamaram a liberdade, e disseram que os Holandeses traziam presos em ferro nas suas naus aos moradores que haviam preso na ocasião do alevantamento, . ., e que êles ditos mancebos achando-se em uma nau na Ilha de Santo Aleixo perto da terra, haviam quebrado os griloes e fugido a nado.." (89). A cadeia pública de então parece não ficar atrás, em defeitos, das exístentes nos dias de hoje. Numa carta ao Conselho dos XIX, os membros do Conselho de Justiça de Pernambuco referem "que os escabinos lançavam à cadeia pessoas presas por dividas, às vezes pessoas respeitáveis", "no mesmo local onde estavam criminosos, negros, ladrões e assassinos, pelo que não sỏ a saúde daquelas pessoas muito se ressentia, como ficavam tão intimidadas que preferiam fugir para os matos abandonando tudo" (90). Gonçalves de Mello, sôbre os presos por dividas fala na promiscuidade existente na Cadeia: “muitos foram presos e trazidos para o Recife, suportando terriveis provações na cadeia, ao lado de vagabundos, desordeiros e ladrões" (91). Foi, possivelmente, a esta Cadeia que também estêve recolhida a mulher de Rodrigo de Barros Pimentel, acusada de haver "agasalhado em sua casa e dado provimento de comer a uma tropa de soldados, que

(88) Frei Manuel Calado, Ob. cit., p. 177, 2.0 vol. Texto n. 24, em anexo.

(89) Frei Manuel Calado, Ob. cit., p. 148, 2.0 vol. Texto $n$. 22, em anexo.

(90) e (91) Ob. cit., ps. 138, nota 289, e 192 respectivamente. Textos nrs. 34 e 37 em anexo. 
havia vindo da Bahia a correr a campanha". D. Jerônima de Almeida, apesar de ser "matrona mãe de nove filhas já quase mulheres perfeitas, e três filhos", foi posta em "uma áspera prisão aonde a não deixavam falar com Português algum" (92).

"Livrar-se sôlto" - Em certos casos, o acusado podia defender-se em liberdade, ou porque a natureza do delito não aconselhasse a sua prisão, ou porque houvesse êle conseguido "um seguro Real para livrar-se solto". Foi o que sucedeu com o Vigário de $\mathrm{S}$. Lourenço da Moribara, porque, "antes de correrem os banhos celebrara o casamento de Fernão Bezerra com Dona Ana Cavalcanti, na casa dos mesmos contraentes. "Sabido isto por o Escolteto Paulo Antônio Damas, mandou prender (o Vigário) e o dito Vigário lhe fugiu, e andou escondido por os matos, e mandou por sua petição pedir ao Príncipe um segurc Real para se livrar solto, e poder aparecer em público, para alegar de sua justiça; levou o Padre Frei Manuel do Salvador a petição ao Príncipe, o qual the concedeu o seguro que lhe pediu" (93). Também conseguiram livrar-se soltos Fernão Rodrigues de Bulhões e Francisco de Azeredo, acusados da morte de um batavo: "porém tanto que o Príncipe se partiu, logo os do Supremo Conselho mandaram vir ao Arrecife a êstes dois homens presos, os quais peitaram largamente, meteram grandes valias para os deixarem livrar soltos, dando-lhe o Arrecife por prisão" (94).

Provas - Passemos, agora, aos meios de prova utilizados pelos flamengos.

Confissão abtida por fraude ou por tormentos -- Em primeiro lugar, procuravam êles obter a confissão dos acusados. Para isto usavam de todos os recursos. Um dêles, segundo Frei Manuel Calado, era a fraude. Os holandeses

(92) Frei Manuel Calado, obs. cit., p. 137 . Texto n. $10 \mathrm{em}$ anexo.

(93), (94) e (95) Frei Manuel Calado, Ob. cit., ps. 141, 1.0 vol., 263 . 
mandavam aos conquenados, como se fôssem sacerdotes católicos, predicantes calvinistas: logo acudiam os pastores protestantes "como lobo carniceiros e lhes metiam em cabeça que eram Sacerdotes, e confessores, e que thes confessassem a culpa, porque os haviam presos, que êles os ajudariam a livrar, e com suas razōes satíricas faziam vomitar a alguns ignorantes as culpas, que se não podiam verificar, senão por suas confissões, e logo iam dizer aos do supremo Conselho, e ao Fiscal o que os pobres ignorantes lhe diziam, às vezes dizendo de suas casas o que nem por pensamento tinham ouvido; e os ministros da justiça, e o Fiscal só com os ditos dos Predicantes pronunciavam a sentença de morte". (95) Usavam também os holandeses, no que, aliás, não estavam sozinhos entre os povos cristãos da época, o tormento como meio para arrancar confissões. Em seu Testamento Político, o conde Nassau mostra-se cético quanto à utilidade de tal sistema: "não recomendo muito as torturas; com elas extorquireis tanto verdades como falsidades e não somente sujeitareis inocentes à suspeita, mas tambénı os perdereis" (96). O uso dos tormentos foi freqüente, sem consideração de pessoa. Por ordem de Frei João da Cruz, seu Prelado, um certo Frei Junípero levou, contra proibição dos holandeses, cartas de Pernambuco à Bahia. Descoberto o fato, frei Junípero foi preso e ia ser pôsto a tormentos, quando confessou o delito: "com o temor do potro que tinha diante dos olhos, e do algoz que se estava preparando" (97). Isto leva a crer que a aplicação do tormento exigia, para certos casos, o auxílio de um potro. Frei Manuel Calado refere outros tipos de tormentos, nem todos, é certo, usados no Recife, mas utilizados pelas tropas em suas campanhas: aós presos "davam cruéis tormentos, metendo-lhes os pés em azeite, e breu fervendo, e a outros enforcando-os por os

(96) Gaspar Barleu, Ob. cit., p. 329.

(97), (98) e (99) Frei Manuel Calado, ob. cit., ps. 106, 17, 276. Textos ns. 7, 4 e 17 respectivamente. 
braços, ou por os pés, e a outros metendo-lhes os dedos nos fechos das clavinas" (98); no ano de 1639, na Alagoa do Sul, o Sargento-mor Mansfelt e o Escolteto Arnau Vandlinberguem. . mandando chamar aos ditos moradores, a saber Sebastião Ferreira morador no Rio de S. Miguel, Manuel Pinto lavrador de canas, Gabriel Soares senhor de engenho, e sem prova alguma, mais do que sua danada tensão, os mandou tratear a todos cruelmente, pondo-lhes fogo debaixo dos pés, do que ficaram aleijados, e a poder de dinheiro com as vidas" (99). De que muitas vêzes as confissões e torquidas eram mentirosas, demonstra de modo eloquente um fato ocorrido com soldados holandeses, que, depois de haverem servido às tropas portuguêsas, voltaram a combater ao lado de seus compatriotas. Demos a palavra a Frei Manuel CaLAdo: "Tanto que os traidores Holandeses foram mandados para a Baía, ordenou um Capitão dos que assistiam nas nossas estâncias mais chegadas ao inimigo uma estrategema notável para fazer que os governadores do Arrecife mandassem enforcar aos sessenta e cinco Flamengos que haviam fugido de entre nós, e se haviam ido para êles; e foi que escreveu uma carta aos do supremo Conselho debaixo de nome de um morador, o qual tínhamos em prisão por as grandes suspeitas com alguma prova que havia de que nos era traidor, e mandava alguns avisos ao inimigo, e mandou por uma das nossas sentinelas perdicas deitar carta de noite junto à porta da fortaleza dos Afogados, para que os Holandeses a achassem (como a acharam, segundo ao depois se soube por um Flamengo que tomamos vivo) e a lessem em Conselho. F a carta dizia desta maneira: "Não entendam Vossas Senhorias que lhe faltam amigos entre os Portuguêses, e porque bem podem conhecer quem é o que esta lhe escreve e lhe manda êste aviso. Vossas Senhorias hão-de saber que êstes dois Capitães Flamengos, que para êsse Arrecife se foram com seus soldados, não vão fugidos, mas antes são traidores, os quais vão por mandado de João Fernandes 
Vieira a solicitar com dinheiro e grandes promessas os ânimos dos Capitães, e soldados dêsse Arrecife, para que o entreguem". Esta carta fêz tanto abalo nos do Supremo Conselho, que sem dar cópia dela a ninguém, deitaram pelo Arrecife espias secretas, que esquadrinhassem os ânimos dos que haviam fugido, e notassem suas palavras, para ver se podiam descobrir neles algum danado intento, que cheirasse a traição. Sucedeu que estando dois dêstes fugidos bebendo alegremente com outros seus patrícios em uma taverna, segundo seu ordinário costume, entre prática perguntaram os outros compatriotas, se os Portugueses faziam bom tratamento aos Holandeses, que andavam no seu exército, e se thes davam boa ração, e lhes pagavam seu soldo com pontualidade de cada mês? Ao que os dois responderam que o tratamento era bom, e que nunca lhes havia faltado a ração quotidiana de farinha, e carne fresca em abundância, para cuja prova tinham ainda suas muchilas cheias de farinha, e carne assada, e que no tocante ao sôldo, todos os meses se fazia pagamento aos soldados razos de cinco patacas, e aos oficiais maior estipendio, segundo os postos, e praças que ocupavam; e para maior prova do que diziam, meteram as mãos nas aljibeiras, e mostraram as patacas e mandaram vir cerveja e aguardente, com que brindaram os circunstantes. Souberam logo disto os do supremo Conselho, e cheirando-lhe a espécie de traição, mandaram prender aos dois, $e$ lhes deram tormento, e suposto que não confessaram coisa alguma, os mandaram enforcar, e aos Capitães mandaram meter em uma fortaleza, para se fazer com êles exame, porém dentro de três dias foram desenganados do enredo, porque um traidor os avisou". (100).

Testemunhas - Admitido que os dois nada houvessem confessado, como teriam sido condenados e por quê? Sem dúvida pelo depoimento das pessoas que com êles haviam

(100) e (101) Frei Manued Calado, Ob. cit., ps. 176-177, e 137, respectivamente. Texto n. $10 \mathrm{em}$ anexo. 
bebido na taverna. Os holandeses davam grande valor à prova testemunhal. Aliás, entre outros, NéLson Hungria afirma ser êste ainda o melhor meio de prova. Aceitavam os flamengos depoimentos de negros contra seus senhores: "com os Holandeses só um dito de um negro lhe bastava para prova bastante para entenderem com os moradores", diz Frei Manuel Calado (101). Mas o pior é que, além de submeterem também as testemunhas aos tormentos, facilitavam o aparecimento de falsos testemunhos. Assim, quando "publicaram um edital com pena de morte que nenhum morador fôsse ousado a ter em sua casa arma alguma ofensiva de qualquer qualidade e condição que fôsse; e que todo negro cativo, que declarasse que seu senhor tinha alguma arma, lhe dariam a liberdade. Começaram a surgir inúmeros depoimentos falsos e muitos flamengos se conluiaram com negros para extorquir dinheiro dos senhores portuguêses" (102).

Outras Provas - Outros meios de prova eram documentos (as cartas trazidas da Bahia para Pernambuco por frei Junípero), o encontro de objetos e, talvez mesmo, exames de cadáveres e ferimentos, dado que as leis puniam os duelos, homicídios e as lesões.

Processo - Infelizmente não nos foi possivel conhecer qual o andamento dos processos crimes no Brasil holandês, quais os meios de defesa do réu, se êle podia apresentar advogados e se existiam êstes advogados no Brasil flamengo.

\section{5 - Dados sôbre o direito penal}

Já vimos que vigorava no Brasil a legislação vigente na Holanda, Zelândia e Frísia. E que leis também podiam ser promulgadas em Pernambuco.

(102) Frei Manuel Calado, Ob. cit., p. 151. Texto n. 14 em anexo. 
Ao que parece, as leis penais eram muitas. Nassau mesmo salientou a necessidade de "abolirem-se as penas dos delitos leves e várias leis, salvas aquelas com as quais se punem os crimes graves" (103). Não tivemos recursos para consultar a legislação acima referida. Procuramos, então, através de diversos textos tirados de Calado, Barleu, Watjen e Gonçalves de Mello, colhêr alguns dados sôbre os crimes punidos no Birasil holandês, bem como sôbre as penas a êles impostas.

De modo algum, a enumeração que faremos esgotará a lista dos delitos de então, mas estamos certos, mostrará os principais dentre êles.

De início, lembremos haver um direito penal militar, caracterizado pelo rigor das penas.

Dentre os crimes militares podemos apontar: saída do soldado com armas, fora do quartel e do corpo de guardas, quando a isto estivesse proibido - pena "de três tratos de corda" (Texto n. 2) ; fazer o soldado agravo a civis e lhes tomar coisa alguma contra sua vontade, quando a isto tivessem sido proibidos - pena de morte (Texto n. 2); agir os militares com pusilanimidade, mêdo, covardia ou pouca diligência, durante os combates - pena de morte (Textos ns. 15 e 16); entregar-se os soldados a saques e pilhagens, descuidando da guarda das próprias armas pena de morte (Texto $n$. 21, relativo às tropas holandesas que, durante algum tempo, serviram aos portuguêses, sob o comando de Teodósio de Estrate, mas referente, sem dúvida, ao direito batavo); trair o militar o exército flamengo - pena de morte (Textos 24 e 25).

Vejamos, agora, os crimes mais comumente atribuidos aos portuguêses: conspirar contra os holandeses - penas de prisão e de confisco de bens (Texto n. 36) e, possivelmente também, pena de morte; escrever à Bahia, receber cartas de lá - pena de morte (Textos ns. 7, 8 e 10) ou de

(103) Gaspar Barleu, Ob. cit., p. 333. 
expulsão do Brasil (Texto n. 43); agasalhar ou tratar com algum soldado que viesse a correr a campanha ou a outra qualquer pessoa que da Bahia viesse - pena de morte: (Textos ns. 3, 10, 11, 7, 8); não declarar aos holandeses quais as pessoas que haviam recebido cartas da Bahia ou. tinham tratado com soldados e pessoas nas condições referidas na frase anterior - pena de morte (Texto $n$. 7); ser ousado a ter em sua casa arma alguma ofensiva de qualquer qualidade ou condição - pena de morte (Texto n. 14); não abandonar localidades das quais tivessem sido mandados sair ou não regressar a outras localidades para as quais houvessem sido convocados pelos poderes da Nova Holanda - pena de morte (Textos ns. 5, 19 e 20); sublevação - pena de morte (Texto n. 40) ; reunir-se e agir em grupos para roubar e matar - pena de morte (Texto. n. 38) ; não plantar o número de covas de mandiocas ordenado por lei - pena de ser considerado inimigo do Estado (Texto 36) e de multa, segundo refere Frei MANuel Calado; vender carne ou matar rês sem licença dos ministros da Câmara - pena de açoites e outras graves penas (Texto n. 18); casar-se ou amigar-se com índios pena de deportação e outras severas penas (Textos n. 42 e $55)$; realizar o sacerdote católico casamento com inobservância das determinações do govêrno holandês — pena de deportação (Texto n. 13); escarnecer o judeu da Igreja cristã ou blasfemar - pena de multa, de prisão e até de mutilação da língua (Textos ns. 30 e 55); casar-se em cerimônia cuja celebração esteja entregue a um sacerdotecatólico - pena de exílio, de multa de 300 florins, ficando os filhos impedidos đe adir à herança (Texto 57).

Outros crimes de maior ou menor gravidade são também referidos pelos autores de que nos valemos. $O$ duelo, por exemplo, era equiparado ao homicidio: "naquele mundo bárbaro irrompiam também contra a nossa gente os. vícios da terra, mormente a infreme mania dos combates singulares, que acabavam em mortes, ferimentos e graves. 
ofensas, com desdouro do nome cristão. Reprimiram-se,... pois, em severíssimos editos, os duelos restabelecendo-secontra os homicidas o rigor das leis" (104).

Nassau, êle próprio, declara: "É do interêsse público: punirem-se com o maior rigor os duelos e os homicídios. deliberados sem se ter em conta a condição de pessoas. Não. são, porém, de punir aquêles que são imperados por uma ira cega ou uma justa dor" (105). Dêste modo, o Conde dava como causas justificativas da ação de matar a ira cega (seria o homicídio passional) e a justa dor (seria o* homicído emocional).

Também a extorsão, os jogos de azar (Texto $n .^{\circ} 55$ ), o . incesto, o adultério recebiam punição.

A prisão por dívidas, embora fuja em tese ao campo. direito penal, era freqüente (Textos ns. 9, 34, 37 e 44).

Passemos, agora, ao exame das penas.

Podemos reunir as penas aplicadas aos delinqüenies. ou aos considerados tais pelos batavos, no Brasil Holandês: nos seguintes grupos: 1 - pena de advertência (Texto $\mathbf{m}_{\text {: }}$ 28) ; 2 - penas de exílio, expulsão e deportação (Textos ns... $13,27,42,43,56) ; 3$ - confisco; 4 - penas pecuniárias (Textos ns. $30,31,32,36) ; 5$ - penas de prisão (Textos n. $\left.^{\circ} 9,30,31,32,36\right) ; 6$ - castigos físicos (Textos ns. $1,12,18,33,35,39,44,55)$; 7 - mutilações e marcas (Tex $\rightarrow-$ tos ns. $12,5,19,35,55,39) ; 8-$ escravidão (Texto n. 41); 9 - pena de morte (Textos ns. 38, 40, 44, 1, 4, 6, 7, 14, 15, $24,38,2,3,10,11,12,14,5,19,29,21$, е 35 ).

A pena de advertência talvez não fôsse pròpriamente. uma pena e, sim, uma medida disciplinar anterior à pena: "como zeladora da decência e dos bons costumes, a autoridade eclesiástica chamou à barra de seu fôro pessoas que se haviam tornado culpadas de adultério ou viviam amancebadas e advertiu, sob ameaça đe imediata demissão, no caso de reincidência, a diversos párocos para que abando-..

(104) e (105) Gaspar Barleu, Ob. cit., ps. 209 e 333 respec- tivamente. 
nassem a sua conduta escandalosa e voltassem ao caminho da virtude, como convinha a um servidor da palavra divina" (Texto n.28).

A pena de expulsão estêve em vias de ser aplicada ao vigário geral que mandara um sacerdote católico celebrar um matrimônio antes de terem corrido os banhos ordenados pelos flamengos (Texto n. 13). Foram também expulsos, logo após a chegada de Kassau, várias pessoas "que haviam cometido roubos, ou eram convencidos de delitos de maior gravidade" (Texto n. 27). Temos a impressão de que a palavra roubo, neste caso não foi empregada no sentido técnico (subtração mediante violência à pessoa) e sim como sinônima de furto, o que é comum em linguagem vulgar. Deportado foi "certo Gaspar Been, ex-alferes que, no Ceará, contra expressa proibição que daqui mandamos, dizem os supremos Conselheiros, que ninguém se unisse aos brasilianos por ser um povo muito cioso (jalours), .. apezar disto amigou-se com uma india" (Texto n. 42). Em 1636, "todos os jesuitas (foram) presos e embarcados para a Holanda. O Conselho Político, indicando as razões para a expulsão informou: "verificamos mais de uma vez, como não era de esperar deles outra coisa, que mantinham correspondência com o inimigo e informavam-no da nossa situação" (Texto n. 43). A expulsão não sera só para a Holanda. BARLEu refere a expulsão de eclesiásticos, que foram mandados para as ilhas das Indias Ocidentais (106). "Em 1641 Paulo Antônio Daens, escolteto de Maurícia, pediu a expulsão de um rico judeu, Gaspar Francisco da Costa "porque êle se tinha feito circuncidar, segundo o uso judeu" (Texto n. 44).

A pena de multa era aplicada aos judeus blasfemadores, sob a capa de esmolas para os pobres: "Ai do Judeu que não pudesse conter a língua" e escarnecesse das práticas da Igreja Cristã. Em tais casos, o Juiz e o Consistório

(106) Ob. cit., p. 211. 
não conheciam compaixão. No fim de dezembro de 1641, um deu-se por muito feliz escapando à morte mediante o pagamento de 4.000 florins para os pobres" (Texto n. 30). Também pesadas multas eram impostas aos contrabandistas (Texto $n$. 32). E a pena de multa era reclamada pela opinião pública para castigo de certos fatos considerados, pelos holandeses, de pequena importância: "Produziu geral indignação no Recife o fato de haver sido conduzido por uma escolta militar, em plena luz do dia, para a prisão o Holandês Luiz Heines, simplesmente por haver dado umas bofetadas num Judeu que usara expressões ofensivas. "Onde iremos parar", exclamava J. V. Razemberg, "quando gente de tão bom nome e irrepreensível conduta é tão duramente castigada, por haver dada umas bofetadas! Para uma ofensa a um Judeu, - portanto, a um blasfemador e traidor do nosso Salvador - certamente uma pequena multa em dinheiro scria suficiente." (Texto n. 31).

A pena de confisco de bens foi aplicada aos chefes de uma conjuração de alagoanos descoberta pelo esculteto Luberg. A um dos condenados foram confiscados uma terça parte de seus bens e a outro, uma metade. Os mesmos conspiradores, Soares e Vaz, foram ainda condenados a prisão: Soares ao confisco de bens e dez anos de prisão; Vaz, ao confisco da metade, dos bens e a vinte anos de prisão no forte de Ceulen (Texto . $^{\circ} 36$ ). Também os judeus "tiveram de expiar os seus desabafos blasfemos com rigorosas penas de prisão" (Texto n. ${ }^{\circ} 30$ ). Penas de prisão foram ainda utilizados, sem efeito prático, para coibir a atuação dos contrabandistas (Texto $n .^{\circ} 31$ ). Além disto já nos referimos à prisão de Luiz Heines, por ter dado umas bofetadas num judeu. Foram freqüentes, segundo nos mostram os Textos ns. 9, 34, 37 e 44, as prisões por dívidas.

Os castigos físicos eram de variada espécie. Pedro Gomes, morador no Arraial velho, certa vez, "achou um seu boi, que os negros do mato tinham já jarretado para lho comerem e o acabou de matar por não se lhe perder a carne, não obstante que o matou com licença de Cosma 
de Castro Passos, que servia de Juiz; todavia o Escolteto o mandou prender e o pôs em termo de ser açoitado na praça pública. Valeu-se o homem do Conde de Nassau, o qual lhe deu perdão da culpa por ser a primeira vez". (Texto . $^{\circ}$ 18). Para os marinheiros dos navios surtos no pôrto também se utiliżava a chibata: "Para essa marinhagem inculta e grosseira que se engajava nos barcos do Brasil e não recuava ante atos de usurpação e violência, tornava-se indispensável manter rigorosa disciplina e inflingir severos castigos aos seus transgressores. Era proibido expressamente aos Oficiais e tripulação pernoitarem em terra. Quando incurso nesta falta, o marinheiro recebia diante do mastro 20 açoites de calabrote. Se ficava fora duas noites, o número de açoites era dobrado" (Texto n. $^{\circ}$ 33). Quanto mais se agravaram os desentendimentos entre cristão e judeus, católicos e calvinistas, e muitos atritos surgiram entre êles, o Alto Conselho achou de bom alvitre estatuir, num edital que "ninguém, de qualquer condição que seja, empregado ou não da Companhia continue a injuriar com palavras ou atos qualquer pessoa de qualquer nação, religião ou condição, ou ainda fazer injuriar por meio de negros ou escravos, ainda dar ocasião a isso; sob pena de serem os perturbadores do sossego público castigados fisicamente" (Texto $n .^{\circ} 44$ ). Não podemos incluir entre as penas os castigos com chicote, vara e correia de couro, impostos pelos senhores aos seus escravos, nem tão pouco o uso de tronco e corrente no pescoço e nas pernas (Textos ns. 35 e 39).

Já as mutilaçôes de membros e marcas de ferro, feitas pelos senhores nos escravos eram de certo modo uma pena, pois só podiam ser feitas depois de autorizadas pelo govêrno (Textos ns. 35 e 39): “O governo holandês mostrou um pouco de interesse pela sorte dos africanos. Permitiam aos senhores certos castigos corporais, como batêlos com o chicote, vara e correia de couro, pô-los nos ferros ou no tronco, acorrentá-los pelos pés e pelo pescoço, 
mas determinou que caberia à justiça, em todos os casos, decretar a morte, penas de mutilações de membros e marcas de fogo" (Texto n. ${ }^{\circ} 39$ ).

De certo modo, a escravidão também foi uma pena aplicada no tempos dos batavos, pelo menos em relação aos indios. Houve um momento "em que se permitiu a escravização dos índios, logo proibida. Tratava-se de índios, que faziam guerra aos que se haviam aliado aos holandeses: como castigo loram escravizados" (Texto $n^{\circ}$ 41).

Mas a pena por excelência, a pena das penas, a mais freqüente nas citaçōes dos autores e a pena de morte. De vários modos era executada a pena de morte: pela fôrca

(Textos ns. 1, 4, 6, 7, 14, 15, 24 e 38), pelo arcabuz (Textos ns. 2, 4), pela espada - (Textos ns. 4, 7, 10, 11 e 15), pela fogueira - (Texto n. ${ }^{\circ} 38$ ), pela entrega da vítima aos índios - (Texto n. ${ }^{\circ} 3$ ), pelo esquartejamento do condenado ainda vivo - (Texto $\mathrm{n}^{\circ}$ 40). Houve casos de verdadeira mortandade: no Rio Grande os Holandeses tinham "ordem para matar todos os moradores de dez anos para cima" (Texto n. ${ }^{\circ}$ 23). Não se tratou evidentemente de uma aplicação de direito penal, mas de um morticínio. Houve vêzes em que a sorte decidiu quem de vários criminosos deveria morrer: certa vez, o Mestre de Campo Teodósio de Estrate, que traíra os holandeses e se passara aos portuguêses, condenou sete Flamengos de seu terço" a que morressem arcabuzeados, segundo as regras da milícia de sua pátria. E porquanto se meteram de permeio muitos rogadores suspendeu a sentença, e mandou que todos sete jugassem as vidas aos dados, e que o que deitasse menos pontos morresse para exemplo; e assim se fez, e se executou a morte no que menos pontos deitou" (Texto n. ${ }^{\circ}$ 21). Há exemplos de execuções coletivas: em Pôrto Calvo, João Cornelicem Lictart, chefe dos holandeses, "deitou bando com pena de morte que nenhum soldado seu fizesse agravo a algum morador, nem lhe tomasse coisa alguma contra 
sua vontade; e porque três soldados sairam do quartel e foram a casa de João Velho Braga, que morava no Varadouro perto da povoação, e lhe mataram um boi de carro, vindo-lhe o dito João Velho fazer queıxa, êle os mandou logo prender, e arcabuzear, e ainda que se meteram muitos rogadores, assim Flamengos, como Portugueses, para que se lhe perdoasse aquela culpa, por ser a primeira, nada foi bastante para que êle revogasse a sentença, e assim morrerram atados a três paus" (Texto n. ${ }^{\circ}$ 2). Tambèm Nassau, de uma feita, segundo refere Frei Manuel Calado, condenou à morte vários de seus comandados: "Tanto que a nossa armada foi derrotando para a parte do Norte tornaram os Holandeses com a sua para o Arrecife, trazendo na sua capitânea um estandarte negro em sinal que vinha nela o seu coronel morto. $\mathrm{E}$ tanto que fizeram fundo, e deitaram âncoras defronte da barra mandou o Príncipe que saíssem os Capitães em terra, e os Pilotos, e tomando informação do que havia sucedido, mandou enforcar a cinco, porquanto na batalha haviam mostrado covardia, e enforcou também a dois Pilotos, porque fizeram pouca diligência para investir com a nossa Capitânea, e ao Almirante do mar mandou degolar em teatro no meio da praça do Arrecife, e o degolaram por detrás por pusilânime e covarde e lhe fizeram em público a espada em pedaços, em sinal de ignomínia, e afronta" (Texto $n .^{\circ} 16$ ). Os casos de pena de morte executada pela fogueira, pelo esquartejamento, pela entrega do paciente aos índios são os que encontram menos referência nos autores. Enforcados ou queimados vivos eram os negros dos quilombos que safam em bandos, roubando e matando (Texto n. 38 ). Esquartejados foram os negros que se sublevaram em Fernando de Noronha: "A sublevação teve Iugar em 1652, parece que causada pela fome. Projetavam os negros matar os poucos brancos que lá havia. O govèrno holandês avisado, aprisionou os cabeças, em número de 6 , que foram condenados a morrer esquartejados vivos. Dois dêles foram 
mortos no Recife, dois em Itamaracá e dois em Fernando "para que o castigo servisse de exemplo" (Texto n. ${ }^{\circ} 40$ ) Entregues aos índios eram os portuguêses acusados haverem acompanhado Matias de Albuquerque: "começaram os moradores a cobrar tanto medo aos indios Caboclos, que mais os temiam que aos próprios Holandeses, porque como eram criados nos matos não lhes fìcava canto que não revolvessem, e bastava dizer qualquer dêles aos Holandeses, êste acompanhou a Matias de Albuquerque ou falou com seus soldádos, para logo o mandarem matar, o que êles executavam como cruéis e carniceiros algozes" Texto n. ${ }^{\circ}$ ). Os meios de execução preferidos são, em primeiro lugar a fôrca, depois o degolamento, e, por fim, o arcabuzeamento. Ameaçados de morrerem degolados estiveram D. Jerônima de Almeida (Texto n. $^{\circ}$ 10) e Julião de Araújo (Texto n. ${ }^{\circ} 11$ ), todos perdoados pelo Príncipe de Nassau. Julião de Araújo, graças às lágrimas da espôsa e de cinco filhos, foi perdoado quando jả estava no teatro das exe cuções e o algóz já se preparava para o degolar. Mortos na fôrca, entre outros, os dois soldados holandeses vítimas da trama da carta falsa urdida pelos portuguêses (Texto n. 24). Condenados à morte estiveram, até perdão do Príncipe, Frei Junípero e seu Prelado. A execução muitas vêzes se cercava de requintes desnecessários de perversidade. O condenado não tinha direito sequer a se confessar e a receber os sacramentos (Texto n..$^{\circ} 12$ ) e, às vêzes, cortavam as mãos do sentenciado antes de o enforcarem, como fizeram a um pobre Domingos Pereira, do Pôrto Calvo, morto por ser soldado e que, antes de morrer destratara o pastor protestante a êle oferecido pelos batavos. A barbaridade ia a ponto de exporem na fôrca os corpos de pessoas que haviam morrido antes da pena executada ou antes de haverem pago as próprias dívidas, como sucedeu com Moisés Abendana, o qual, cheio de débitos se enforcara: "a Câmara dos Escabinos tomou, então, uma resolução estranha, proibiu o enterro do judeu e determi- 
nou que o corpo fôsse pôsto em exposição na fôrca" (Textu n. ${ }^{\circ}$ 4.4). E quando o condenado não podia ser levado à fôrca, vivo ou morto, restava o recurso à execução em efígie. Sucedeu isto ao traidor Teodósio Estrate e a seu sargento-mor segundo lhe fêz saber uma carta a êle dirigida: "Sois um infame cachorro, e traidor dos Senhores Estados e Companhia, que com tão pouca vergonha, tendovos feito Governador da fortaleza de Nazaré, que era a melhor que tínhamos nesta costa, a entregastes aos Portugueses, e agora com tão pouco pejo os estais servindo na guerra como velhaco e infame. Pela qual razão os Senhores do Supremo Conselho vos condenaram logo à morte; e ao vosso Sargento-mor, Francisco de la Tour, que basta ser francês, para também ser traidor. E assim a vós degolaram em estátua por detrás como infame e logo vos queimaram à vista de todo o povo, e a vosso Sargentomor enforcaram e logo Ihe fizeram a estátua em quartos, e os puseram pendurados da fôrca, pelo que vossa vida e vossa honra não têm remissão para conosco" (Texto $n^{\circ}$ 25).

Um último reparo sôbre os dados que colhemos com relação ao direito penal flamengo no Brasil: a freqüência com que o Conde de Nassau, chefe supremo do país, procurou atenuar a brutalidade dêste direito rude e de guerra, perdoando os condenados ou comutando-lhes as penas.

\section{Lista de textos:}

Frei Manued Calado, O Valoroso Lucideno - Edição Cultura São Paulo. Dois volumes.

\section{$1 .^{\circ}$ Volume}

Textos n.os:

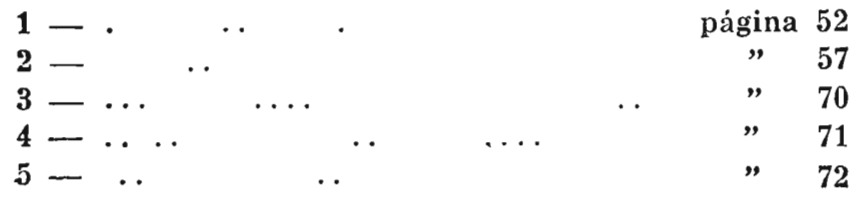




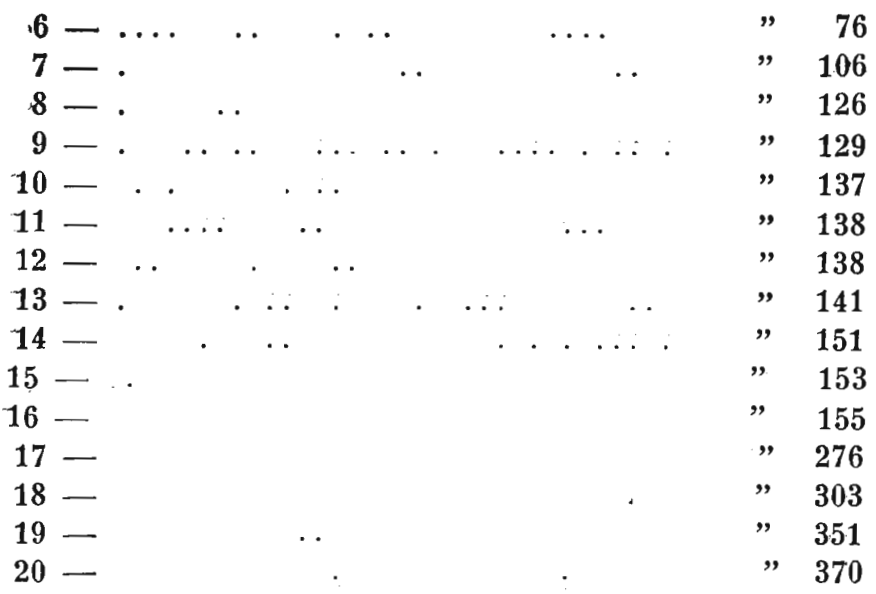

\section{Volume}

Textos n.os:

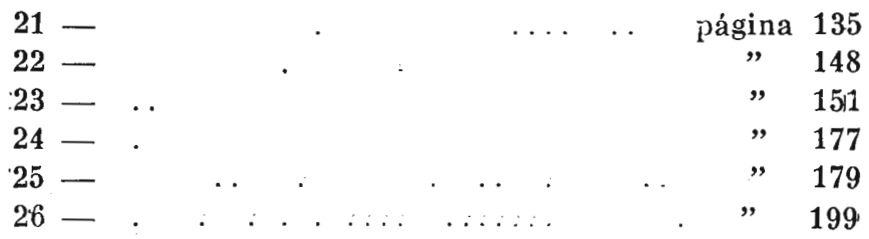

Hermann Watjen, O Domínio colonial holandês no Brasil. - Companhia Editôra Nacional — São Paulo

Textos $n .{ }^{\circ} \mathrm{s}$ :

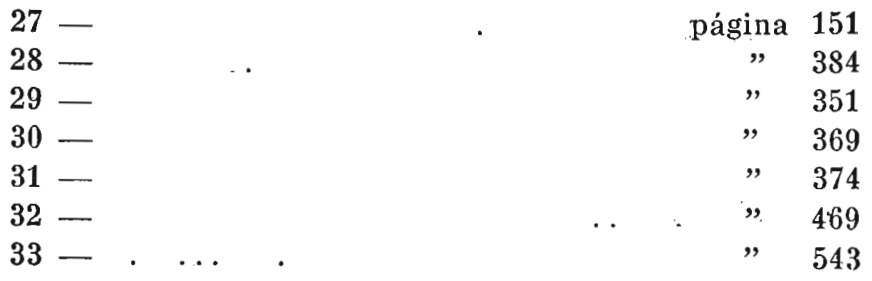


José António Gonsalves de Mello, Tempo dos Flamengos.

Textos n.os:

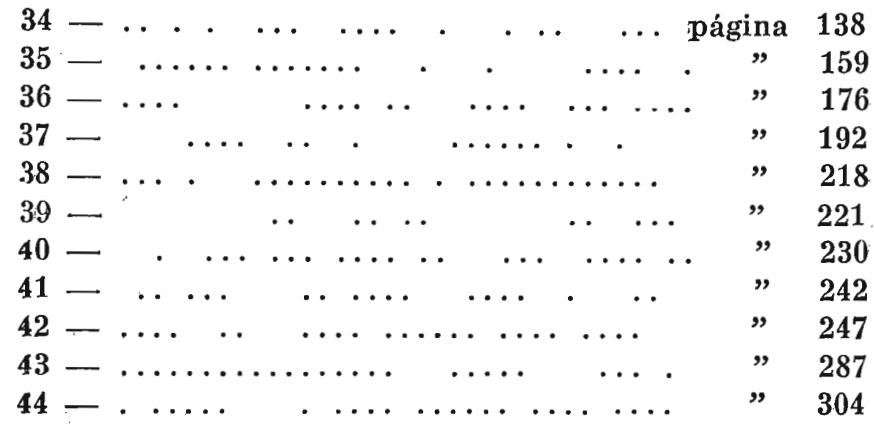

Gaspar Barleu, História dos feitos recentemente praticados durdnte oito anos no Brasil e noutras partes sob o governo do ilustríssimo João Maurício, CONDE DE NASSAU, etc., ora governador de Wessel, Tenente General de Cavalaria das Provincias Unidas sob o Principe de orange.

Edição do M. de Educação - Rio - 1940

Textos n.os:

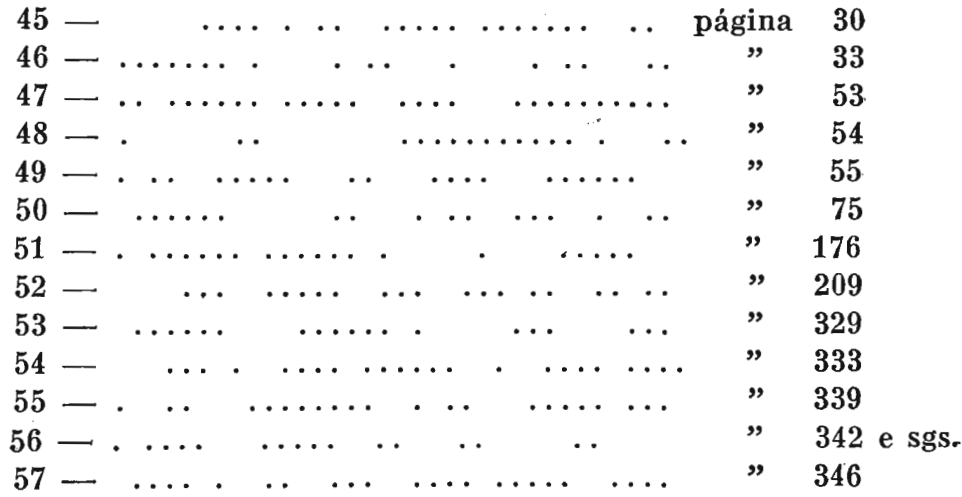

Pôrto Seguro, História das lutas com os holandezes no Brasil desde 1624 a 1654 - Trep. Castro Irmão — Lisboa - 1872. Texto $n^{0}$.

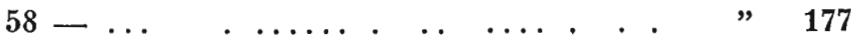

